\title{
To discover a Drowned Body
}

Florence Peacock , Philip Redmond, Leland L. Duncan , Bryan J. Jones \& W. B. Yeats

To cite this article: Florence Peacock, Philip Redmond, Leland L. Duncan , Bryan J. Jones \& W. B. Yeats (1899) To discover a Drowned Body, Folklore, 10:1, 114-123, DOI: 10.1080/0015587X.1899.9720486

To link to this article: http://dx.doi.org/10.1080/0015587X.1899.9720486

曲 Published online: 14 Feb 2012.

Submit your article to this journal $\pi$

Џll Article views: 1

Q View related articles $₫$ 


\section{MISCELLANEA.}

To discover a Drowned Body.

At an inquest held on the 2 nd November last, at Everdon. near Daventry, on a young lady who had drowned herself, it appeared that it was generally thought by the country people that the deceased had drowned herself in Sir Charles Knightley's great fish-pond, in Fawsley Grounds.

Edwin Bird, a farm labourer, employed by the deceased's father, told the Coroner that his master ordered him to take a loaf and some quicksilver down to the pond to find the body.

The Coroner. - How were you to do that?

Witness.-My master was told that if he got a penny loaf and put some quicksilver in it, it would show where the woman was drowned.

The Coroner. - What did you do ?

Witness,-I made a hole in the loaf and put the quicksilver in, stopped the hole up, and then threw it into the pond. Master was told that when the loaf floated over the body it would jump about.

The Coroner.---How absurd 1

Witness added that the loaf floated about the pond, but it gave no indication that the body was there. Ultimately the body of the deceased was found in a brook, some distance away, in about four teet six inches of water.

The jury returned a verdict of suicide whilst temporarily insane.

Standard, Nov. 23, ×898.

On the 26 th November, the Standard published a letter from a correspondent containing the following extract from the Gentleman's Alagazine for 1767 (i. 189): 
"A child near two years old fell into the River Kennet and was drowned. After diligent search had been made in the river, but to no purpose, a twopenny loaf, with a quantity of quicksilver put into it, was set floating from the place where the child had fallen in, which steered its course down the river upwards of half a mile, before a great number of spectators, when the body happening to lay on the contrary side of the river, and gradually sunk near the child, when both the child and loaf were immediately brought up, with grabbers ready for that purpose."

We cannot find this passage in the volumes hitherto published of the Gentleman's Magazine Library. The superstition is well known, but it is interesting to record so modern a case as that at Everdon.

\section{Midnight Children.}

A few days ago my sister was told by a Lincolnshire peasant woman that "a midnight child" has peculiar gifts: "it can see everything"- that is spirits and other supernatural beings. My sister has also lately been told that the old nurse of a young man who is a clever amateur actor attributes his powers to the fact that he was born at midnight.

It is a common belief that people born on the midnight which links together Christmas Eve and Christmas Day have wonderful gifts; but it is new to us that all midnight children are endowed beyond others.

Florench Peacock.

\section{AUGURIES.}

In the Mayer Collection at Liverpool is a Latin Psaller of the latter part of the thirteenth century, the front and back fly-leaves of which are formed of portions of a manuscript of the Parcifal by Wolfram von Eschenbach. This manuscript of the Parifal must have been cut up and destroyed by the monks in order to 
bind the Psalter. On the last page of the Psalter itself there is some German writing, in a hand of the fourteenth century and in the Swabian dialect, which has been translated by Dr. Priebsch Lecturer on the English Language in University College, Liverpool. The first seven lines run as follow: "He who is born on a Sunday will become strong and beautiful; he who is born on a Monday will become strong; he who is born on a Tuesday will become strong and eager for combat; he who is born on a Wednesday will become judge of the empire; he who is born on a Thursday will become an honest man; he who is born on a Friday will have a long life; he who is born on a Saturday will not live long." Then follow a number of auguries from dreams, concerning which Dr. Priebsch makes the suggestion that they are extracted from some old book of dreams. Most of them are identical with superstitions on the subject still current. Such an augury as "To dream of having long hair betokens strength" may perhaps be derived from the Biblical story of Samson. Another, "Prosperity will come to him who dreams of talking with the dead," seems to be derived from some sort of ghost-worship. The last one is "Great joy and a great name are signified by dreaming that one picks up a cabbage." May we all pick up cabbages in dreams 1 Dr. Priebsch has published facsimiles of the fragments of the Parifal with some introductory remarks, including a transcription and translation of all these auguries, in the Bulletin of the Liverpool Museums, vol. i., Nos. 3 and 4.

\section{IRISH FOLKLORL.}

\section{The Little Red Iten: A Nursery Tale.}

I have often heard the following story in Ireland, when a child, from my nurses and others. I have heard it since, and set it down exactly as it was told. This is the only version I know of.

Once upon a time, and a very good time it was, a cat, a rat, and a little red hen lived together in a little house. The cat had a nice warm well-lined basket, the rat a nice snug hole, and the little red hen a comfortable perch. 
One fine morning the little red hen said: "Who'll get up and light the fire?"

"I won't," said the cat.

"And I won't," said the rat.

"I'll do it myself," said the little red hen. So she got up and lit the fire. Then she said: "Who'll get up and sweep out the room?"

"I won't," \&c.

Then she said : "Who'll get up and get the breakfast?"

"I won't," \&c. Then she said: "Who'll get up and eat the breakfast?"

"I will!" said the cat.

"And I will!" said the rat.

"No, I'll do it myself," said the little red hen. But she let them have their breakfast. Then she said: "Who'll clear away the things ?"

"I won't," \&c.

But while she was clearing away the things, whom should she see coming up the street but the fox. And the cat ran into its basket, and the rat into its hole, and the little red hen flew up on her perch.

In came the fox. "Good day to you, little red hen," said he. "Come down and scratch my back." So she flew down on his back and began to scratch it. And when she came near his head, he put up his paw, and brushed her off and caught her; and he put her in his bag, and away with him.

Now it was a hot day, and he soon got tired; so he lay down under the shadow of a church, and went to sleep. And the little red hen took a scissors and a needle and thread out from under her wing, and cut a hole in the bag. And out she got, and put a big stone into the bag, and sewed up the hole; and away with her home to the cat and the rat.

After a bit the fox woke up and put his bag on his back, and started off home again. "Much good that rest's done me!" said he. "Why, she feels heavier now than when I lay down!" However, he got home at last, and bade his old mother make ready the family glass pot, because he had the little red hen in his bag.

So she got out the family glass pot and filled it and put it on the fire; and it was so big that it filled up the opening of the 
hearth, and the fox had to go out and climb up on the roof, and drop the contents of his bag down the chimney. And so he did; and the big stone fell down and knocked the family glass pot into bits. And when the mother saw this, she was so angry that she took off her wooden shoc, and ran out of the house, and knocked him off the roof with it. ${ }^{1}$

\section{Hampden Club, Phœnix Street, N.W.}

PhiLip Redmond.

\section{Method of Starting a New House in the Olden Times.}

Perhaps the following, told me by a man at Kiltubbrid, co. Leitrim, may interest the society :

The ground for the house having been measured out, a sod would be turned at the four corners. The four sods would be left for two or three nights, to see if the proposed house were on a fairy "walk," in which case they would surely be found replaced, and another site would have to be found. If nothing occurred, a hen or some such small animal would be killed, and the blood allowed to driy in the four holes, after which the house might be proceeded with. ${ }^{2}$

A new house is such a rarity in the neighbourhood now that I can get no testimony as to recent procedure.

1 This story evidently consists of two distinct stories imperfectly welded together. An amusing version of the former of the two is given by $M$. Rent Basset from Ech Cherichi, Conmentaire des Maqdmat do Mariri, Boulaq, 1300 A.H. (1882-3 A.D.). A parasite accompanied a traveller. When they arrived at a place where they were to stop, the traveller said to the parasite : "Take a dirhem, and go and buy us some ment." "Go yourself," said the parasite ; I am weary." The man accordingly went himself and bought the food. Then he said to his companion: "Get up and cook this," The para. site refused; and so un for the successive requests to break the bread and draw the waler. When the traveller at length had made all ready, he said to the parasite: "Get up now, and eat." "Yes," said the other; "why should I contradict you any longer? By Allah! I am ashamed of having contradicted you so often." And he arose and sat down to eat. Rev. des Trad. Pop., vol. xiii., p. 225. - ED,

- $C f$. the customs in the Fxroe Islands and Sweden cited by Mr. Feilberg

Zeitschrift der Vereins für Volkskunde, vol. viii. p. 273.-ED. 


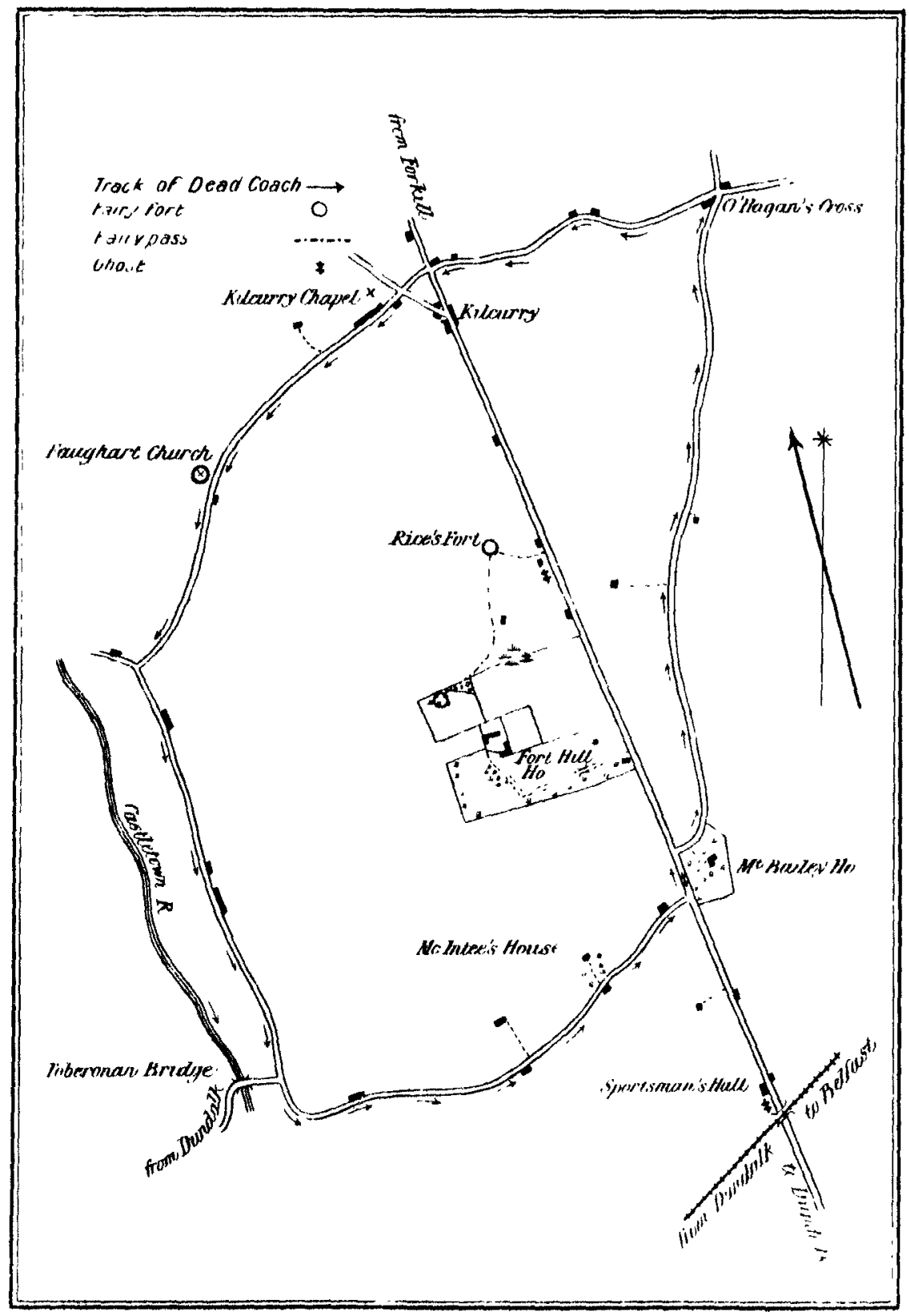

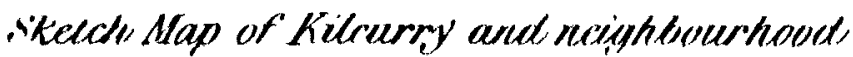

Iis fint peep: /II" 


\section{The Couvade?}

Another little saying has been reported to me, viz.: When a man's wife is about to give birth to a child, folk will chaff him and say: "You'll soon have to go to bed with the old woman and be nursed like they did years ago." Can this possibly be a faint reminiscence of the Couvade?

Leland L. Duncan.

\section{Traditions and Superstitions collected at Kilcurry, County Louth, IrELAND.}

\section{[Authorities.}

Thomas Curtis, a farm labourer, about fifty years of age; he is well educated, and has lived in England.

Harry McIntee, a small farmer, age about forty.

Margaret Collins, age about forty-five, a native of Co. Cavan, now living on the Forkill Road, just outside Dundalk. She lives principally on charity.]

1. Whenever anyone in the parish is about to die, the Dead Coach is to be seen on the road shown in the sketch-map. It goes southwards from Faughart Church, past the turn to Toberonan Bridge, across the Forkill Road, by Mount Bailey, to O'Hagan's cross-roads, and thence by Kilcurry back to the church again. The coach is black, drawn by four headless horses, and driven by a headless driver ; it is perfectly noiseless, "like a bicycle," Seeing it does not appear to bring any ill-luck to the beholder; II. McIntee has seen the coach on the road near his own house, -[H. McIntee, T. Curtis, and others.]

2. Faughart Church, now disused, was built about the beginning of this century. It stands upon an ancient fort, and the following story concerning its building is current in the neighbourhood:

When Mr. Linley, the rector, was looking for a site for his church, he wished to buy Rice's Fort for the purpose, but the owner refused to sell it, so the present site was purchased instead The church was begun, and the work proceeded favourably. One evening, when the building was almost completed, the contractor 
was returning homewards to Dundalk with his men; on Toberonan Bridge he turned to look back at his work, and saw to his horror that it was wrapped in flames. In despair he wished to return, but was dissuaded by his workmen, who argued that by the time he arrived on the scene it would be too late to effect anything. In the morning the contractor returned and found the church unharmed; the fairies had not been able to do more than manifest their displeasure. The church has been called "Belchinny," or the "Church of Fire," ever since.--[T. Curtis and others.]

3. There was an old man named Johnny McKeown, who lived in a little house by the roadside close to Rice's Fort. He used to say that one night he was sitting by the fire and he heard a noise on the road, so he went and opened the door and looked out. It was a bright moonlight night, and he saw a regiment of soldiers coming down the road towards him. They were very tired-looking and foot-sore, and "drabbed," and they came right into his yard, marching two and two, several hundreds of them. They went into the field behind, and on into Rice's Fort. Of course it was the "gentry" coming back from some fight between themselves, $-[\mathrm{T}$. Curtis.]

Nore.-Rice's Fort is said to contain a cave, or subterranean chamber, with a passage ending in the little marsh between it and Fort Hill. There is said to be a similar passage from the fort at Fort Hill to the marsh. The two forts are connected by a "fairy pass;" and one night, when Curtis and another man were standing beside this path, they heard a sound like many horses galloping past quite close to them.

4. Johnny McKeown's yard was haunted at night by a big black dog, whose arrival always set his own dog howling. He took it to be the ghost of a man who used to work for him.

5. The ghost of a former occupant of Mount Bailey is said to walk on the road near the house. My informant could not give any reason for this, as the gentleman in question-a bank manager in Dundalk - had been a good neighbour and an "unmeddling man."-[T. Curtis.]

6. "There was a man I knew, a working man up at Lurgan Green, and one night he got up, I suppose it was towards daybreaking, and opened the door. And I don't know what the divil took him, but he went and stood out on the road, and him in his nightdress. He had hardly been there a minute before he was 
lifted up, and he didn't know where he was going till he was on the top of Faughart Hill. And in the morning when the halfpast five horn blew he was lifted up and dropped twenty perches from his own door. And one of the other workmen says to him, 'Where were ye the morning, Jemmy?' And he says, 'I was on the top of Faughart Hill with the gentry'"-[H. McIntee.]

NoTk. - This anecdote, which I took down immedjately afterwards, as far as possible in his exact words, was related by McIntee in the course of a conversation I had with him some years ago, He stoutly maintained the existence of the fairies, while denying that of ghosts. Faughart Hill lies about two miles to the eastward of Kilcurry; on it are a holy well and ruined church dedicated to Saint Brigid, as well as a fort marking the site of her nunnery.

7. Beside the road from Dundalk to Kilcurry stands a farm. house, called from the surrounding townland Sportsman's Hall. It is a modern two-story brick house, built on to a much older cottage which is unoccupied, the doors and windows being nailed up. The people around say that the cottage contains the ghost of the farmer's father, which they say haunted the family so constantly after the old man's decease that they were obliged to have it shut up there. Prayers were said to prevent the ghost from escaping from its prison.-[T. Curtis.]

8. A woman, now dead, but whose daughter still lives in Kilcurry, was once carried off by the fairies. She was walking one night beside a stream, when she saw what appeared to be a woman sitting on the opposite bank, wailing and "batting the water with its hands." On crossing to the other side, the woman was seized and carried off to a fairy fort, where she remained several days, but she would neither eat nor drink, and prayed so hard to be sent back to her children that in the end they had to let her go.-[T. Curtis.]

9. Directly a man's spirit leaves his body it has to travel over all the ground he travelled over while alive, and during this time it is visible.-[T. Curtis.]

All the souls in suffering are released for forty-eight hours yearly, commencing on Holy Eve (October $3^{1}$ ) and including All Saints' and All Souls' Days. - [T. Curtis.]

10. "If the first lamb you see in the season be white it is lucky, but if it be black you will die within the year."-[Margaret Collins.] 
Ir. When the mother of a man named McKeown, living near Kilcurry, was dying, a pigeon flew into the house and out again, while at the same time there was a tap on the window. This was a death warning. - [T. Curtis.]

Bryan J. Jones.

Mr. Clodd having shown the above notes to Mr. W. B. Yeats, the latter gentleman kindly forwarded the following memoranda upon them:-

I have stories about most of the things in the slip of folklore you send. I will be dealing with a good many of the subjects in a month or two.

(1.) The coach is very common; Mr. Jones is perhaps wrong in calling it "the Dead Coach." The people of co. Galway usually call it "the Deaf Coach," because it makes a "deaf" sound. They describe "deaf" as muffed or rumbling. I never heard before of its being suundless. Has he mistaken "deaf" for "dead"? ?

(2.) I am always hearing of forts and of certain rooms in houses being seen as if on fire. It is the commonest phenomenon in connection with forts, in all parts of Ireland I know.

(3.) I am collecting material about fairy battles, and am trying to find out when they coincide with May Day, or November Day, or thereabouts, or else with a death.

(4.) A Newfoundland dog, according to my uncle's old servant, is "a very quiet form to do your penance in." She is a Mayo woman and very much of a saint. ${ }^{3}$

(6.) It is always dangerous to go out late at night. I have a number of Galway and Sligo stories of people being carried to a distance, including one in which I myself am supposed to have been carried four miles in County Sligo. Compare the spiritualistic medium, Mrs. Guppy, being carried across London with a saucepan in one hand and an egg in the other. She weighed about nineteen stone. I have met about four peasants who believe in

I Both "Dend" and "Deaf" are perhaps corruptions of "Death." Mr. Jones, however, has kindly promised to make further inquiries about the word used by the Louth people; but to the best of his belief they always speak of "the dead coach."-Ev.

- Mr. Jones writes that he has been told that this form is the one usually assumed by evil spirits, -ED. 
fairies but not in ghosts. I have never met the converse, though I have met a man in Co. Roscommon who denied both, but believed in water-horses.

(7.) A ghost has to go anywhere it is sent; but if you send it to an unpleasant place, you have to do your own penance there when you die. My uncle's old servant again.

(8.) Am greatly interested in the fairy "batting the water with her hands." A man at Ballesodare, Paddy Flynn, used the same phrase about the Banshee. ${ }^{1}$

(9.) I never heard this about the soul travelling where it had gone in life. It is very interesting."

(10.) I have heard of the fairies putting a black lamb into a flock as a warning to a Sligo relation of my own who had cut a fairy bush. In a couple of days the lamb vanished. I suppose therefore that black lambs are uncanny.

(Ir.) I have a friend whose family (an old Kerry family, I think) has this death-warning.

W. B. Yeats.

\footnotetext{
'Mr. Jones writes: "As far as I can remember, Curtis thought the figure sitting by the water was the Banshee."-ED.

- Mr. Jones writes that he has never heard of the belicf elsewhere in Ireland, but refers to a note in Morris' Saga Library, vol, ii., The Saga of the EreDwellers, p. 282, where the translator says: "To this day the belief exists in Ireland that the spirit of the dead visits all localities on earth where the person has been, before it passes to its final destination. This journey is supposed to take a miraculously short time."-ED.
} 